\title{
Disentangling the Mutual Feedback Relationship between Extreme Drought and Flood Events and Ecological Succession of Vegetation
}

\author{
Biqiong Dong1, Tianling Qin*, Shanshan Liu', Fang Liu ${ }^{1,2}$, Hanjiang Nie, ${ }^{1,3}$ \\ Jianwei Wang ${ }^{1}$, Zhenyu Lvi, ${ }^{1,}$, Xiaoqing Shi ${ }^{1,3}$
}

${ }^{1}$ State Key Laboratory of Simulation and Regulation of Water Cycle in River Basin, China Institute of Water Resources and Hydropower Research, No. 1 Fuxing Road, Haidian District, Beijing 100038, China

${ }^{2}$ State Environmental Protection Engineering Center for Pollution Treatment and Control in Textile Industry, College of Environmental Science and Engineering, Donghua University, No. 2999 Renminbei Road, Songjiang District, Shanghai 201620, China

${ }^{3}$ Department of Hydraulic Engineering, Tsinghua University, No. 30 Shuangqing Road, Haidian District, Beijing 100084, China

Received: 27 March 2020

Accepted: 17 June 2020

\begin{abstract}
In the context of climate change, the extreme precipitation events over most of the mid-latitude land masses and over wet tropical regions will very likely become more intense and more frequent, which may cause increases in the intensity and frequency of extreme drought or flood events. To explore the mechanism of dynamic and functional changes in ecosystems driven by extreme drought and flood events (EDFEs) in the future and the interaction between the two, this study focuses on the mutual feedback relationship between EDFEs and the ecological succession of vegetation. To accomplish this target, we reviewed relevant studies of the impacts of EDFEs on vegetation ecology (including growth status and living states) and that of feedback of ecological succession of vegetation to EDFEs. This study is of great significance for accurately predicting the future dynamic succession of plant communities, and the circulation of materials of future ecosystem with ongoing climate change, which provides fundamental and scientific basis for the establishment of ecological protection and restoration strategies in response to frequent climate extremes.
\end{abstract}

Keywords: the Mutual Feedback Relationship, extreme drought and flood events, ecological succession of vegetation

*e-mail: qintl@iwhr.com 


\section{Introduction}

In the context of climate change, the number and frequency of extreme weather events worldwide are increasing and the extreme precipitation events over most of the mid-latitude land masses and over wet tropical regions will very likely become more intense and more frequent [1]. As for extreme precipitation events, different scholars have slightly different definitions of their connotations. Some scholars regard the precipitation events with 1- to 7-day precipitation totals exceeding specific station-specific thresholds as extreme precipitation events, such as the precipitation events in upper 5 percentile of a probability density function of observations or with 1 year or 5 years recurrences [2]. According to IPCC [3], an extreme weather event would normally be as rare as or rarer than the $10^{\text {th }}$ or $90^{\text {th }}$ percentile of a probability density function estimated from observations. Some researchers hold that extreme climatic events are characterized by their statistical extremeness combined with their discreteness relative to the life span of the organisms in focus [4] or with the feature of changing the structure and function of the ecosystem beyond its normal variability [5].

The extreme drought and flood events (EDFEs) refer to extreme hydrological events caused by extreme precipitation events with relatively long recurrence periods. The EDFEs described in this study are the drought or flood events caused by the relatively discontinuous precipitation with probability density functions estimated from observations at $10 \%, 90 \%$, or with 5 years recurrences.

The EDFEs consist of single extreme drought or flood event and multiple extreme drought and flood composite events. Multiple extreme drought and flood composite events are classified to repeated extreme drought or flood events, and extreme drought and flood abrupt alteration events (Fig. 1). The drought and flood abrupt alteration events (DFAA) are generally believed as persistent drought for certain continuous days in one basin or region, followed by sudden heavy precipitation, resulting in steep river water and farmland waterlogging [6]. The drought duration in DFAA varies among different studies, ranging from several ten days [7], months [8] to quarters and years [9]. The term "extreme drought and flood abrupt alteration events" in this study refers specifically to an extreme drought event following by an extreme flood event.

Climate change forecasts of more frequent climate extremes suggest that such events including the EDFEs will become increasingly important drivers of future ecosystem dynamics, function and services [10-12]. Nonetheless, how can the EDFEs drive future ecosystem dynamics, function and services potentially? According to some scholars, the EDFEs possibly drive species range shifts and influence physiological processes, which may affect the provisioning of ecosystem dynamics, function and services [13].

Taking vegetation, which is the major producer of ecosystem as an example, growth and survival of vegetation may be perturbed along with shifted physiological processes and species range under the impact of the EDFEs. The EDFEs result in dramatic changes of available water for vegetation in soil, which may affect vegetation growth status [14-18]. Some EDFEs with long duration may endanger vegetation survival, such as causing canopy dieback, whole tree mortality, and entire forest mortality [11,19], which probably trigger ecological succession of vegetation. Meanwhile, we assume that the ecological succession of vegetation might exert feedback on EDFEs. Therefore, this study based on the hypothesis that there is mutual feedback relationship between EDFEs and ecological succession of vegetation.

Disentangling the mutual feedback relationship between EDFEs and the ecological succession of vegetation provides a referential example to understand and reveal the relationship between climate extremes and ecosystem dynamic and function, which is important for prediction of circulation of materials of future ecosystem. Despite the effects of EDFEs

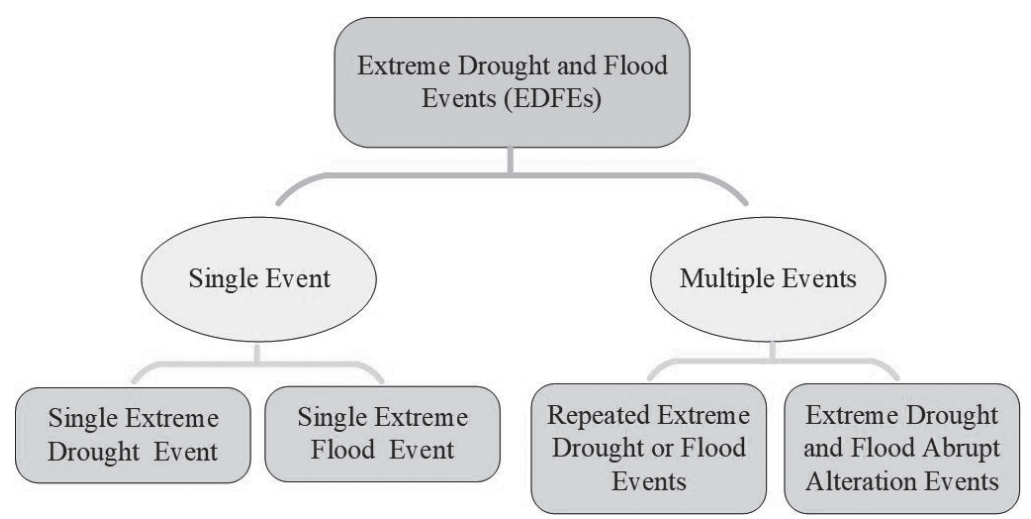

Fig. 1. A schematic diagram explaining different types of extreme drought and flood events (EDFEs). The term "Repeated Extreme Drought or Flood Events" represents the repeated and relatively discontinuous extreme drought or flood events. The term "Extreme Drought and Flood Abrupt Alteration Events" refers specifically to an extreme drought event following by an extreme flood event. 


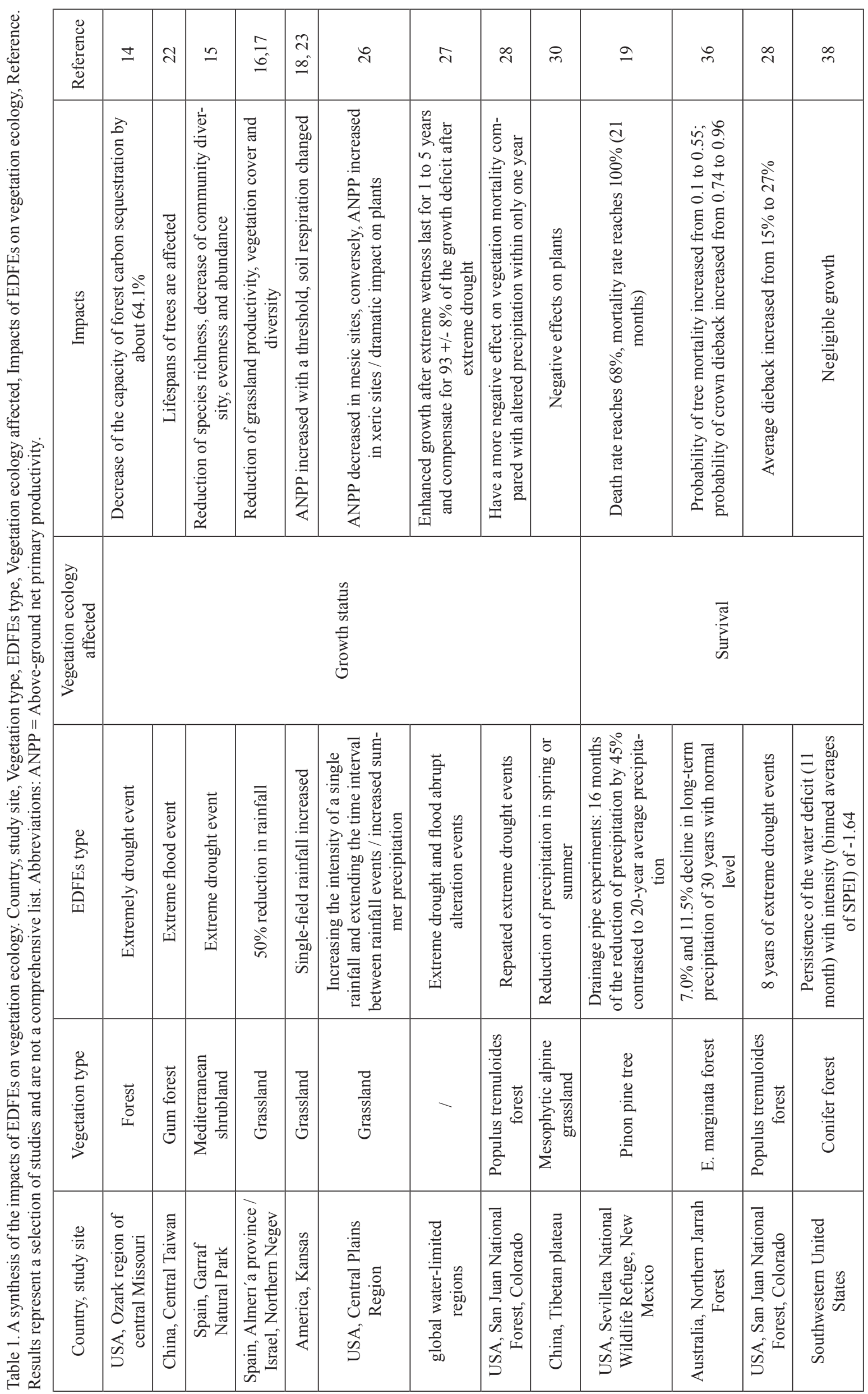




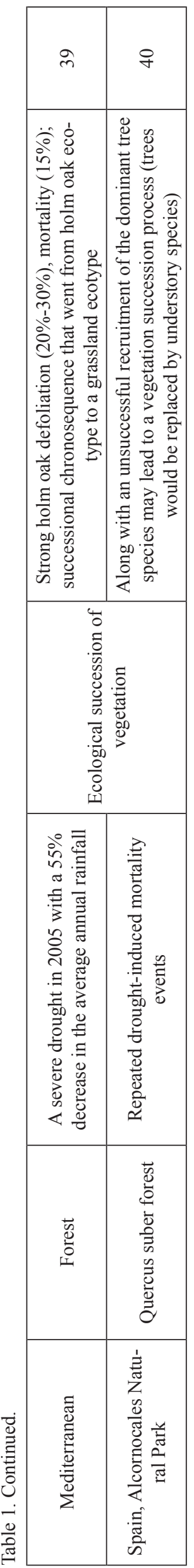

on vegetation ecology have been extensively studied, the mutual feedback relationship between EDFEs and the ecological succession of vegetation still remains unknown.

This study focuses on disentangling the mutual feedback relationship between EDFEs and the ecological succession of vegetation. To address this issue, several electronics databases (Web of Science Core Collection, Korean Journal Database, Russian Science Citation Index, SciELO Citation Index) were searched for English-language articles reporting three aspects: (1) the effects of EDFEs on vegetation ecology, (2) the underlying mechanism of the impacts of EDFEs on vegetation ecology, (3) feedback of ecological succession of vegetation to EDFEs. This study contains a comprehensive review of different studies in the above three aspects, which provides the mechanism of dynamic and functional changes in ecosystems driven by extreme drought and flood events (EDFEs) in the future and the mutual feedback relationship between EDFEs and the ecological succession of vegetation. The results are of great significance for accurately predicting the future dynamic succession of plant communities and circulation of materials of future ecosystem with ongoing climate change, which provides fundamental and scientific basis for establishment of ecological protection and restoration strategies in response to frequent climate extremes.

\section{Results and Discussion}

\section{The Impacts of EDFEs on Vegetation Ecology}

Based on observations and analyses, the EDFEs influence vegetation ecology by affecting growth status and survival of vegetation, which may promote ecological succession of vegetation (Table 1). To elucidate the underlying mechanism which drives the ecological succession of vegetation, we investigate the underlying mechanism and manifestation of vegetation mortality caused by EDFEs (Fig. 2).

\section{Observations and Analyses}

\section{(1) Growth status}

The impact of EDFEs on the growth status of vegetation is reflected in the possible changes in the net primary productivity (NPP) of the vegetation, which can lead to changes of physiological, ecological indicators on leaf scale, canopy scale, plant scale, population scale, community scale and landscape scale. The impact of single extreme drought or extreme flood event on growth status of vegetation is restricted by severity, duration and occurrence time in the year of single extreme drought or extreme flood event and the resistance and resilience of vegetation [20-21]. Compared to single extreme drought or extreme flood event, the impact mechanisms of multiple extreme 


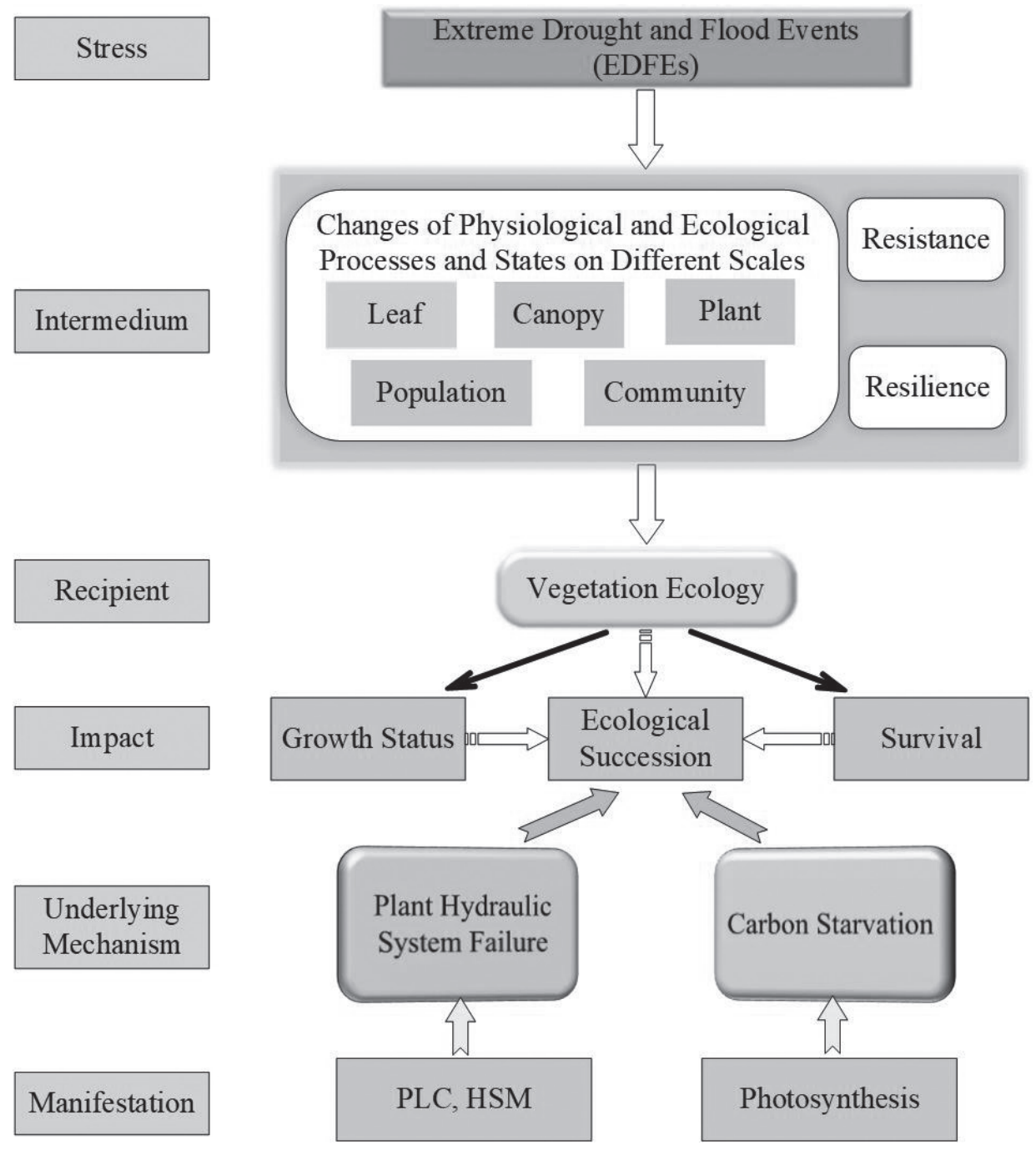

Fig. 2. Conceptual figure of the impacts of EDFEs on vegetation ecology. The solid arrows represent the confirmed relations under certain conditions, while the dotted arrows represent the probable relations.

drought and flood composite events on vegetation ecology are more complex, with impacts of different events interacting synergistically or antagonistically. Moreover, the seasonal distribution of EDFEs and sensitivity differences of vegetation cover types to the events may also influence the impacts on growth status of vegetation.

1) Single event

The water scarcity owing to the extreme drought event (8-day average rainfall is at or below the lowest point of the multi-year average) in summer of 2012 together with heatwave severely decreased the capacity of forest carbon sequestration by about $64.1 \%$ in Ozark region of central Missouri, USA [14]. The extreme flood events probably affect the lifespans of trees. Multiple regression analysis indicates that factors such as species, tree diameter at breast height, distance from sampled tree to the above boundary of sample plot (far from the riverbank), and distance from the upstream of the river affect the lifespans of trees after extreme flood events [22].
Based on the results of 17 years drought experiment (with a decreasing trend of $40 \%$ in precipitation), Liu D.J. et al. [15] found that the extreme drought events significantly reduce species richness in Mediterranean shrubland, the extreme drought events also obviously decreased community diversity, evenness and abundance. Meanwhile, the extreme drought events increase the relative species richness and abundance of shrubs.

For grassland ecosystem, extreme drought or flood events can also affect its productivity. The study of Miranda J.D. et al. [16] reflects that $50 \%$ reduction in rainfall reduces grassland productivity, vegetation cover and diversity, Rakefet S.N. et al. [17] finds the similar results. Fay et al. [18] increased single-field rainfall of grassland in the Kansas, America through rainfall control experiments. The results showed that aboveground net primary productivity (ANPP) increased with enhanced photosynthesis, and a threshold exists for increased biomass. In semi-arid grassland, apart from ANPP, soil respiration (R-s) is also sensitive to 
changes in growing season precipitation (GSP), this responsiveness to GSP peaks at moderate levels of extremity, and declines at the most extreme GSP levels [23]. The study of Li W.T. et al. [24] indicates that with mean annual precipitation lower than $600 \mathrm{~mm}$, the greening of the savannas and grasslands in the Sahel is found to highly correspond with the increased precipitation.

2) Multiple events

Harper C.W. et al. [25] found that a $30 \%$ reduction in annual precipitation lead to decreases of the average soil moisture content by $11 \%$ and that of ANPP by $9 \%$; extending the drought period between extreme flood events to 1.5 times of the original reduced the average soil moisture content by $19 \%$ and the ANPP by $9 \%$; the average soil moisture content reduced by $23 \%$ and the ANPP reduces by $18 \%$ under the combination of the two above treatment. The results of this type of experiments show that by changing the seasonal distribution of rainfall during the year, increasing the intensity of a single rainfall and extending the time interval between rainfall events, the extreme precipitation decreases ANPP in mesic sites, but, conversely, increased ANPP in xeric sites [26].

The effects of EDFEs on vegetation ecology are not isolated. When multiple extreme drought and flood composite events occur, their impacts on vegetation ecology may be more complicated. As for the impacts of extreme drought and flood abrupt alteration events on growth status of vegetation, enhanced growth after extreme wetness was found to last for 1 to 5 years and compensate for $93+/-8 \%$ of the growth deficit after extreme drought across global water-limited regions according to Jiang P. et al. [27]. However, we note that the impacts of repeated extreme precipitation events, such as repeated extreme drought events, even years apart from each other, are also likely to have a more negative effect on vegetation mortality compared with altered precipitation within only one year [28].

3) Seasonal distribution of events

Differences in seasonal distribution of EDFEs in the year may have significantly different impacts on growth status of vegetation. The underlying mechanism may be that the seasonal distribution of extreme precipitation in the year is a critical factor in determining soil microbial- and plant-productivity. It affects the vegetation ecology indirectly by affecting soil temperature and soil humidity, and then combining with soil microbial processes. Ou Y. et al. [29] verified that an extreme flood event in Songhua River in August 2013 had prominent effects on the soil physicochemical conditions, enzyme activities and soil microbial composition of riparian wetland.

Whether EDFEs occur in growing season may have diverse effects on vegetation ecology. In the mid-plant growth season, higher temperature and soil moisture elicit positive synergistic effects on plant growth and soil microbial processes [30]. Reduction of precipitation in spring or summer generally has negative effects on plants, associated with reduced SWC, while subsequent reduction in autumn or winter has little effect on SWC or plants. Similarly, increased summer precipitation has a more dramatic impact on plants than winter increases in precipitation [26].

4) Sensitivity of different vegetation cover types

Responses of vegetation to water stress vary in different vegetation cover types. Grasslands are most responsive to extreme drought events followed by forests and desert vegetation [31]. Persistent extreme drought events may also have legacy effects on vegetation growth, which cause reduced vegetation growth. Wu X.C. et al. [32] shows that legacy effects of extreme drought events on vegetation growth differ markedly between forests, shrubs and grass across diverse bioclimatic conditions over the temperate Northern Hemisphere. Specifically, deep-rooted forests exhibited a drought legacy response with reduced growth during up to 4 years after an extreme drought, whereas shrubs and grass had drought legacy effects of approximately 2 years and 1 year, respectively. An assessment of the terrestrial carbon flux responses to extreme drought in Southwest China in 2009 reflected that across different vegetation types, forests and shrubs have stronger capability of drought resistance and shorter post-drought recovery time than crops and grasses [33]. Sensitivities of different plant functional types (PFT) to extreme drought events also vary from each other. Through simulation experiments among C-3, C-4 grasses and shrubs, David L.H. et al. [34] reveals that the $\mathrm{C}-3$ grasses are the most sensitive $\mathrm{PFT}$ to drought, the $\mathrm{C}-3$ shrubs are the most resistant, and the $\mathrm{C}-4$ grasses and shrubs have intermediate drought sensitivities. Lawson J.R. et al. [35] surveyed dominant species at 15 riparian sites along rivers across southeastern Australia and found that extreme flood events with average recurrence of 10-20 years show strong positive relationships with mean wood density. This study indicates that mean wood density in riparian communities is probably driven by powerful but relatively rare flow events.

\section{(2) Survival}

EDFEs which last for a certain period of time, may cause drastic changes in vegetation ecology. For instance, persistent extreme drought events probably lead to tree mortality or increase the probability of mortality. Continuous extreme flood events may also cause tree damage or mortality [11]. McDowell N.G. et al. [19] conducted drainage pipe experiments in Sevilleta National Wildlife Refuge, New Mexico, USA, and showed that after 16 months of the reduction of precipitation by $45 \%$ contrasted to 20 -year average precipitation, the death rate of the pinon pine reaches $68 \%$, and after 21 months the mortality rate reaches $100 \%$. Matusick G. et al. [36] found pronounced legacy effects associated with chronically reduced long-term precipitation (LTP) (1951-1980 versus 1981-2010) at the tree level. When comparing areas experiencing $7.0 \%$ and $11.5 \%$ decline in LTP with a normal level, 
the probability of tree mortality increases from low $(<0.10)$ to high $(>0.55)$ in both species, and probability of crown dieback increased from high (0.74) to nearly complete (0.96) in E. marginata. After experiencing 8 years of extreme drought events in the San Juan National Forest, Colorado, USA, the average dieback rate of Populus tremuloides gradually increased from $15 \%$ to $27 \%$ in July 2011 and to $38 \%$ in July 2012 [28]. Kramer K. et al. [37] used multivariate analysis to find that flooding duration, flooding depth and flooding velocity can explain $19 \%, 11 \%$ and $8 \%$, respectively, of the variation in damage and mortality of trees.

Moreover, persistent extreme drought events significantly reduce tree growth rates. A strong correlation was found between the binned averages of tree growth-related ring width index (RWI) and standardized precipitation evapotranspiration index (SPEI) at the regional-scale under dryer conditions [38]. Predicted by the correlation of the regression model, persistence of the water deficit (11 months) with the intensity of -1.64 leads to negligible growth for the conifer species (Pinus edulis and Pinus ponderosa) in the Southwestern United States.

(3) Ecological succession

After the mortality of vegetation caused by persistent EDFEs, the ecological succession of vegetation may be promoted under the natural state or with artificial intervention. A study focused on Mediterranean forests showed that the region suffered a severe drought in 2005 with a $55 \%$ decrease in the average annual rainfall. This drought resulted in a strong holm oak defoliation (around $20-30 \%$ of the total population) and mortality (15\%). Consequently, this woodland showed a successional chronosequence that went from holm oak ecotype to a grassland ecotype [39]. On the longterm, repeated drought-induced mortality events, along with an unsuccessful recruitment of the dominant tree species in forests may lead to a vegetation succession process where trees would be replaced by understory species (such as drought-tolerant shrub) [40]. In the process of ecological succession of vegetation, the impacts of vegetation on local hydrological process of a catchment or region may change correspondingly.

\section{Underlying Mechanism}

Most researches on the underlying mechanism of the impacts of EDFEs on vegetation ecology focus on the mechanism of vegetation mortality induced by EDFEs, with less attention to the influential mechanism of EDFEs on growth status. Therefore, this study mainly summarizes the mechanism and manifestation of tree mortality caused by EDFEs. The research on the mechanism of tree mortality caused by extreme drought events has made beneficial progress, while the research on the mechanism of vegetation mortality caused by extreme flood events has been relatively less.

(1) Possible mechanisms
What are the possible mechanisms of tree mortality caused by persistent extreme drought events? Studies have shown that the relationship between drought and tree mortality is more complicated than that between drought and grassland productivity [41]. Because of this, the mechanism of tree mortality caused by extreme drought events has not been comprehensively analyzed and confirmed. Nonetheless, scholars represented by McDowell N.G. et al. [42], Choat B. et al. [43], and Liu Y.L. et al. [44] have reached certain consensus on the mechanism of tree mortality caused by extreme drought events. They hold the view that tree mortality caused by extreme drought events may occur through several mechanisms, including plant hydraulic system failure, carbon starvation, phloem transport limitation and biotic attack. Extreme drought events cause reduction of available water for plant in soil, which lead to decrease of xylem water potential. To maintain water balance, most trees choose to reduce the stomatal conductance of the leaves until the stomata closed and cavitation generated. At a critical threshold of drought stress, cavitation increases rapidly and gas emboli spread throughout the xylem and loss of xylem hydraulic conductance increases sharply. As the extreme drought events continue, embolic in the xylem extends to the entire hydraulic transmission system of the plant (including roots, stems and leaves), which represents completely failure of plant hydraulic system.

On short time scales, these consequences include a rapid cessation of photosynthetic $\mathrm{CO}_{2}$ assimilation, loss of canopy evaporative cooling through transpiration and greater probability of photodamage. Over longer time scales, low photosynthetic rates associated with drought-induced stomatal closure can lead to depletion of non-structural carbohydrate pools. Moreover, both translocation of sugars through the phloem and the production of chemical defensive compounds needed to prevent herbivory and disease may be interfered, which could reduce forest defenses against biological attacks.

Although the mechanisms of tree mortality caused by persistent extreme drought events especially phloem transport limitation and biotic attack are far from fully understood. It is basically certain that the tree mortality is mainly related to low plant water potential and the decrease of photosynthesis rate. This study mainly explores the persistent extreme drought events which trigger tree mortality by affecting plant hydraulic system.

(2) Manifestations

The low plant water potential under extreme drought events can generally be characterized by the water potential at certain loss of the hydraulic conductivity of plants. The minimum recovery water potential of conifers has been found to correspond to the water potential at $50 \%$ loss of xylem hydraulic conductance (P50) [43]. Different from coniferous forests, the mortality thresholds in angiosperms are found to be associated with more complete hydraulic dysfunction, 
which are the water potentials at the $80-100 \%$ losses of xylem hydraulic conductivity (PLC), expressed as P88 [45-46]. Other hydraulic thresholds for mortality have been proposed, including a sustained loss of hydraulic conductance greater than $60 \%$ [19].

Simulated pinon pine trees that died in August 2008, 1 year after installation of the drought treatment, achieve a maximum PLC of c. $80 \%$ and a minimum non-structural carbohydrates (NSC) of $40 \%$ of their starting NSC pool just before mortality. However, the two indicators are not applicable for other surviving pinon pines [19]. Predicting PLC of soil-canopy continuum in pinyon-juniper woodland suggested that none of the trees go 'critical' (PLC $=100$ ), but trees of both species that ultimately die are unique in spending over $50 \%$ of their growing season days at a PLC $>68$ $[19,47]$. A link between branch PLC $>70$ and dieback is found in Juniper, oak species growing naturally in Texas [48] and ironbark and bloodwood species in Australia [49]. Extensive studies of natural aspen have associated mortality with PLC $>60$ in root and stem segments, with the potential for a long lag time between PLC-inducing drought and ultimate death [50-51].

Furthermore, HSM of tree (difference between xylem minimum water potential and water potential under a certain loss of hydraulic conductivity), synthesizing complex drought responses that involve integration of stomatal and hydraulic responses, is used for prediction of tree mortality risk. By analyzing the results of 33 studies worldwide, Anderegg W.R.L. et al. [52] find that the HSM from P50, P50 and P88 are the only significant predictors of cross-species patterns of mortality anomalies across all species combined.

Studies have also shown that Juniper may be less likely to have simple mortality thresholds. Juniper trees dropped foliage progressively during drought and exhibit gradual canopy loss from 2007 to 2013 and whole-tree mortality during 2010-2013 [53].

The commonly used hydraulic thresholds for mortality such as P50 are not constant values, which may change among different tree species or within the same tree species temporally and spatially. Anderegg W.R.L. [54] calculated the coefficient of variation of stem P50 and found that the intra-specific CV of P50 varied both in time and in space, with slightly higher variability temporally than spatially. Angiosperms exhibited higher intra-specific spatial variability than gymnosperms in P50. This study reflects the degree of variation of P50 among different kinds of plants, which is crucial for investigating the hydraulic responses of plants to extreme drought events. However, there still remains a gap for the researches of the variation of P88 among different tree species or within the same tree species temporally and spatially.

(3) Probable causes of differences in manifestations

The differences in hydraulic thresholds for the mortality between coniferous forest and angiosperm may be caused by the differences of xylem structure between the two. Tori exist in the center of the pit membrane of coniferous trees, while not in that of angiosperm. When tori are inserted into round or oval pits with thickened edges, they will cause the pits to close, preventing gas exchange between the tracheid. The presence of pit plugs in the xylem of coniferous trees prevents water from entering the other tracheid or ducts through the pits under extreme drought conditions. Thus, the water confined in the tracheid or duct that produces the embolism in coniferous trees can't be used by coniferous trees, which may lead to the lower lethal hydraulic conductance of xylem in coniferous trees than that in angiosperms [55].

\section{Feedback of Ecological Succession of Vegetation to EDFEs}

Compared with the impacts of EDFEs on vegetation ecology, the ecological succession of vegetation may apply feedback to EDFEs (Fig. 3). The basic theory of this feedback refers to the impacts of vegetation ecology on local hydrological process. During the ecological succession of vegetation, local hydrological processes changes accordingly, which may change the capacities of the basin for mitigation or exacerbation of the extreme events.

\section{Basic Theory}

The basic theory of feedback of ecological succession of vegetation to EDFEs relies on the impacts of vegetation ecology on local hydrological process. The direct impacts of vegetation ecology on local hydrological process are exerted through root water absorption and stomatal transpiration. The indirect impacts involve the influences of the canopy structure and the community distribution on precipitation, soil moisture, slope runoff and evapotranspiration from vertically and horizontally respectively [56].

The influences on precipitation mainly manifest in the canopy interception and stem redistribution of precipitation, of which the canopy interception is mainly affected by vegetation types, canopy density and forest structure complexity [57-59].

Apart from root water absorption, vegetation ecology also affects soil moisture and slope runoff by changing soil infiltration capacity and deep seepage recharge [60]. Root channels characteristics, below-ground biomass can determine the soil infiltration rates as well [61-62]. The hydraulic redistribution mechanism of the root system may change the distribution of surface soil water and deep soil water [63]. Additionally, vegetation types, vegetation coverage and NDVI are related to evapotranspiration [64-65].

Consequently, most studies have demonstrated the beneficial effects of vegetation in reducing surface runoff under different environmental conditions, while the effects on groundwater are complicated and divergent [66-68]. 

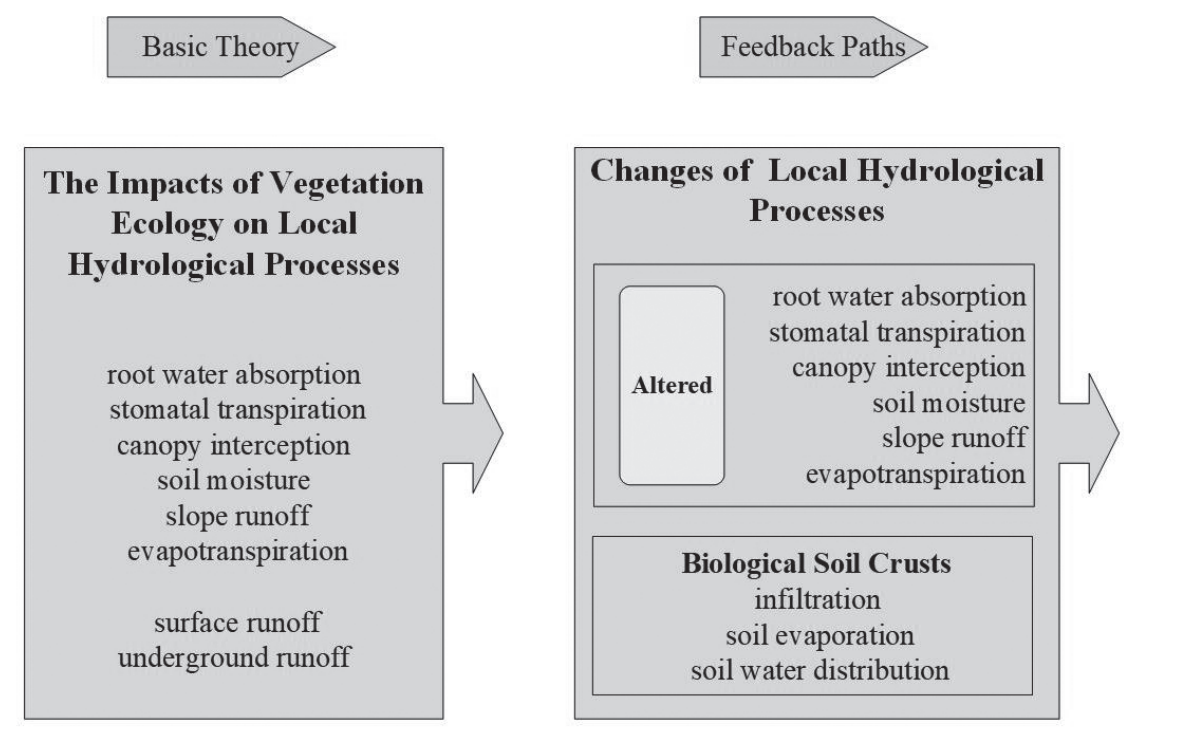

Feedback

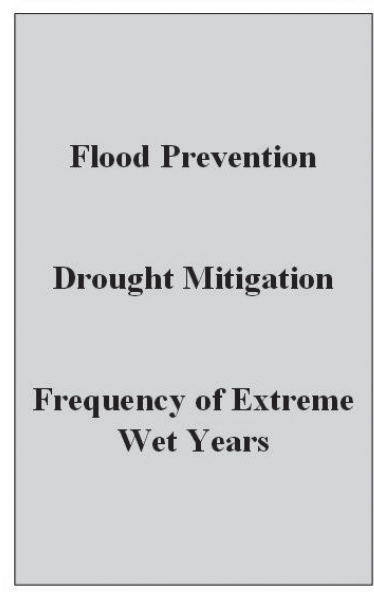

Feedback of Ecological Succession of Vegetation to Extreme Drought and Flood Events

Fig. 3. Conceptual framework shows the feedback of ecological succession of vegetation to EDFEs. Biological soil crusts (BSCs) formed on the surface of the sand dunes as vegetation succession proceeded in the arid or semi-arid desertification areas [77]. BSCs can also profoundly change hydrological processes by affecting precipitation infiltration, soil evaporation and soil water redistribution.

\section{Feedback Paths}

According to the aforementioned basic theory, the feedback paths lie in local hydrological processes changes caused by ecological succession of vegetation.

The vegetation mortality can be regarded as a signal of vegetation succession. The vegetation mortality may have impacts on the runoff yielding and flow concentration process of local hydrological cycle. Loss of canopy cover from tree mortality directly decreases transpiration and canopy interception of precipitation, sometimes leading to increases in soil moisture, run-off and recharge [69]. Tree mortality may cause increases in SWC, and the changes of soil moisture at the dead trees during drought and rainfall events are both significantly different from that at normal growing trees [70].

Studies also show that changes in surface runoff may be unobvious over a longer period of time after tree mortality. 10 years after tree mortality, streamflow changes in most basins following die-off are not detected, while one basin consistently shows decreased streamflow [71]. Time-trend analysis reveals post-dieoff streamflow decreased in three catchments by 11$29 \%$, with no change in the other five catchments. This observation may be related to inter-annual variation of precipitation and different tree types and forest coverage.

During forest succession, canopy interception and surface runoff may change significantly. In the first decade of forest recovery, canopy interception loss increased to levels of mature forests in a tropical forest region of Panama, which may have potentially undesirable consequences for the entire flow regime [72]. With increasing trends of vegetation indexes of the Loess Plateau in northern Shaanxi since 1986, a negatively correlation between the annual runoff and NDVI or ET was found [65]. The peak flow differences existed in the paired watersheds with similar characteristics of watershed area, elevation, and soil properties but different forest cover in Ecuador in South America. Nevertheless, as the size of the precipitation event increases, the effects of forest cover and afforestation on the peak discharge become less important [73].

During natural vegetation restoration following grassland-shrubland-forestland succession, the soil water storage (SWS) and water yield of the basin under different vegetation covers change accordingly. In the same year, the SWS was highest in grassland, intermediate in shrubland, and lowest in forestland. Moreover, the SWS in grassland and shrubland was significantly higher in August 2014 than in August 2005, but the pattern was reversed for forestland [74]. By analyzing 94 watershed experimental studies, Bosch J.M. and Hewlett J.D. [75] inferred that coniferous forest, deciduous hardwood, shrub and grassland have (in that order) a decreasing influence on water yield of the basin in which these covers are manipulated. Coniferous and eucalypt cover types cause approximately $40 \mathrm{~mm}$ change in annual water yield per $10 \%$ change in forest cover. Deciduous hardwoods are associated with a $25 \mathrm{~mm}$ change in yield per $10 \%$ change in cover, while $10 \%$ changes in shrub or grass lands seem to result in about $10 \mathrm{~mm}$ change in annual yield. In general, changes 
in annual water yield caused by forest cover reduction of less than $20 \%$ can't be detected by hydrometric or streamflow measurement methods [76].

In the arid or semi-arid desertification areas, as vegetation succession proceeded, biological soil crusts (BSCs) formed on the surface of the sand dunes [77]. BSCs can alter patterns of SWS, the soil bulk density, the soil water-holding capacity. For example, the development of BSCs increase the moisture content near the surface $(0-5 \mathrm{~cm})$ while decrease the moisture content in deeper layers $(5-120 \mathrm{~cm})$ [78]. BSCs can also profoundly change hydrological processes, such as precipitation infiltration, soil evaporation, soil water redistribution and the water balance of the original soilvegetation system [77, 79].

\section{Feedback}

The ecological succession of vegetation exerts feedback on EDFEs by changing the capacities of the basin for mitigation or exacerbation of the extreme events.

Beier C.M. et al. [80] reanalyzed one of the earliest ecosystem experiments in North America with the 1963 de-vegetation of a forest and compared water flow regulation capacity between experimental watershed (deforestation area) and reference watershed over 30 years. Based on his results, during the time of de-vegetation and initial recovery, experimental watershed has a marginally lower likelihood than reference watershed of flood prevention after moderate to high amounts of precipitation (100-175 mm), while experimental watershed has a higher capacity than reference watershed for drought mitigation.

Conversion from native deciduous catchments to dense pine monocultures reduces annual streamflow in both extreme wet- and dry-event years, which may exacerbate low flows and drought, but it may also potentially mitigate high flows and flood risk. Managing catchments with species conversion treatments could decrease the apparent frequency of observed extreme wet-event years on average by a factor of seven compared to an unmanaged catchment [81]. In this type of treatment, the choices of tree species are key determinant factors of response intensities. For example, tropical and subtropical species conversions to Eucalyptus hybrid plantations might exacerbate streamflow responses to extreme dry years even more than a pine plantation [82].

\section{Conclusions and Prospect}

The Mutual Feedback Relationship between EDFEs and Ecological Succession of Vegetation

EDFEs affect the vegetation ecology by changing the available water for vegetation in the soil, including the impacts on the growth and survival status of vegetation.

The impact of EDFEs on the growth status of vegetation is reflected in the possible changes in the net primary productivity (NPP) of the vegetation, accompanied with the changes of physiological, ecological indicators on leaf scale, canopy scale, plant

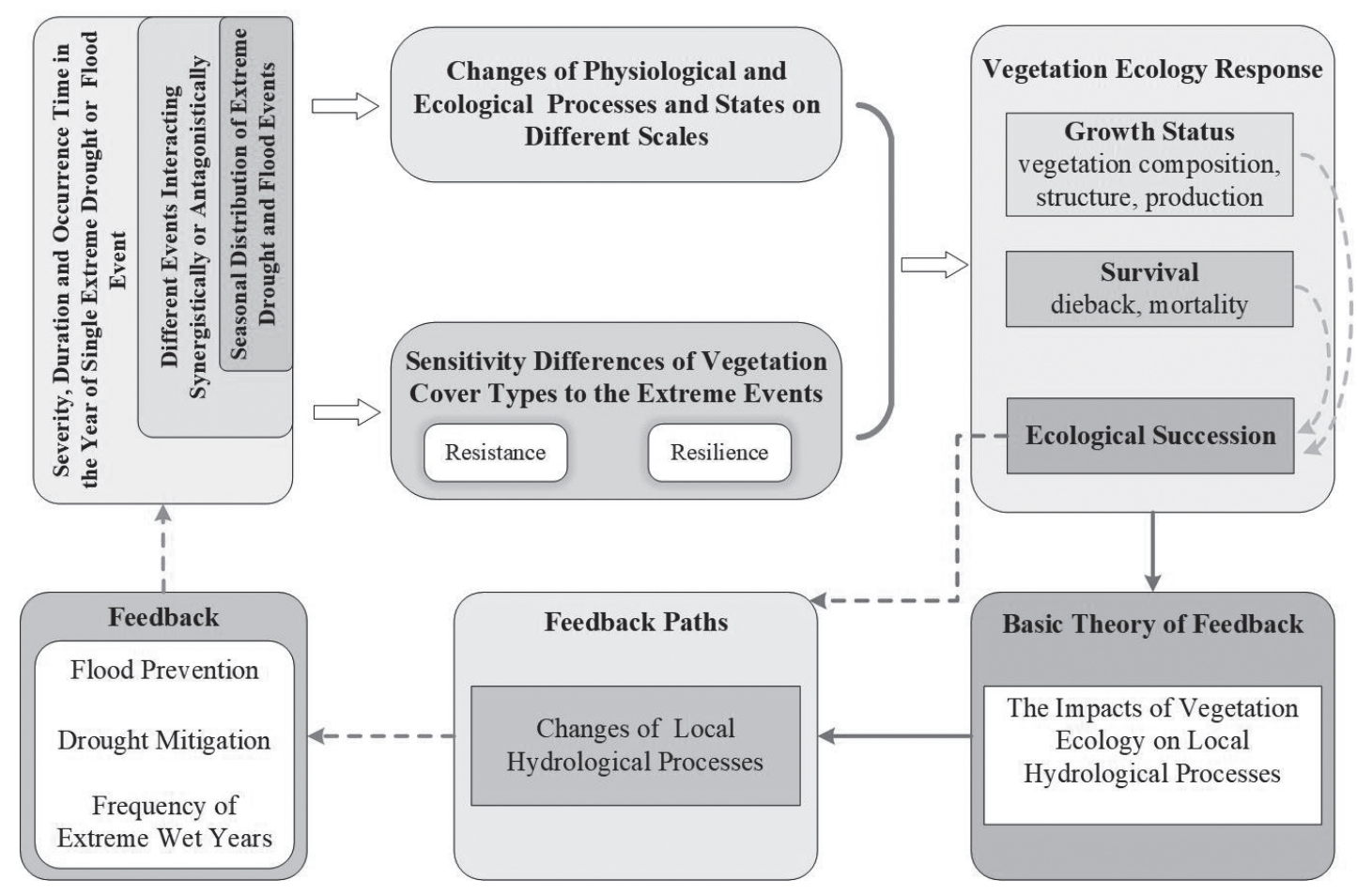

Fig. 4. A conceptual framework which shows the mutual feedback relationship between EDFEs and ecological succession of vegetation. The solid arrows represent the confirmed relations under certain conditions, while the dotted arrows represent the probable relations. 
scale, population scale, community scale and landscape scale. The impact of single extreme drought or extreme flood event on growth status of vegetation is restricted by severity, duration and occurrence time of the event and the resistance and resilience of vegetation [20-21]. While the impact mechanisms of multiple extreme drought and flood composite events on vegetation ecology are more complex, with impacts of different events interacting synergistically or antagonistically. Meanwhile the seasonal distribution of EDFEs and sensitivity differences of vegetation cover types to the events may also influence the impacts on growth status of vegetation.

Persistent EDFEs may also endanger the survival of vegetation, leading to tree mortality or increasing the probability of tree mortality. Although the mechanisms of tree mortality caused by EDFEs are complicated and far from fully understood, it is basically certain that tree mortality is mainly relevant to low plant water potential and the decrease of photosynthesis rate. After vegetation mortality caused by persistent EDFEs, the ecological succession of vegetation may be promoted in the natural state. The application of artificial intervention may also change the ecological status of vegetation, which both lead to changes of the impacts of vegetation on the hydrological processes.

During the ecological succession of vegetation, the impacts of vegetation on canopy interception, evapotranspiration, infiltration, and the processes of overland flow concentration and soil water movement may have changed, which can cause alterations in quantities of soil water content (SWC), surface runoff and underground runoff. These changes possibly influence the abilities of vegetation to prevent extreme flood events and mitigate extreme drought events, and the frequencies of EDFEs and peak flow in the basin may change accordingly. Therefore, the mutual feedback relationship between EDFEs and ecological succession of vegetation has developed (Fig. 4).

\section{Summary of Hot Issues for Future Research}

This review indicates key research gaps in understanding the mutual feedback relationship between EDFEs and ecological succession of vegetation. Most researches in this field focus on the impacts of a single extreme drought or flood event on the vegetation ecology, our current understanding of the underlying mechanisms of the effects of multiple extreme drought and flood composite events on vegetation ecology is relatively lacking. With the increasing variabilities of EDFEs under climate change, the occurrence possibility of multiple extreme drought and flood composite events increases. In this context, it is essential to study the mechanism of how the multiple extreme drought and flood composite events may affect the vegetation ecology to enhance the ability of the ecosystem to cope with extreme drought and flood risks under frequent climate extremes in the future.
Existing studies generally acknowledge the differences in the sensitivities of vegetation types to EDFEs. Studies which quantitatively characterize such differences are relatively scattered in the globe and lack a summary of the laws applicable to different climatic zones around the world. In the future, it is necessary to carry out synthetical researches on the sensitivities of different plant functional types to EDFEs in different climate zones. Meanwhile, to provide technical support for vegetation ecological adaptive management under frequent climate extremes, ecological risk assessment of vegetation in different regions of the world caused by EDFEs are urgent.

\section{Acknowledgements}

This research was supported by the National Key Research and Development Project (Grant Nos. 2017YFA0605004 and 2016YFA0601503) and the National Science Fund for Distinguished Young Scholars (Grant No. 51725905).

\section{Conflict of Interest}

The authors declare no conflict of interest.

\section{References}

1. IPCC (Intergovernmental Panel on Climate Change). Climate change 2014: Synthesis Report. Cambridge University Press: Cambridge, Britain

2. EASTERLING D.R., MEEHL G.A., PARMESAN C., CHANGNON S.A., KARL T.R., MEARNS L.O. Climate extremes: observations, modeling, and impacts. Science, 289 (5487), 2068, 2000.

3. IPCC (Intergovernmental Panel on Climate Change). Climate change 2013: The physical sciences basis. Cambridge University Press: Cambridge, Britain 2013.

4. JENTSCH A., KREYLING J., BEIERKUHNLEIN C. A new generation of climate-change experiments: events, not trends. Frontiers in Ecology and the Environment, 5 (7), 365, 2007.

5. SMITH M.D. An ecological perspective on extreme climatic events: a synthetic definition and framework to guide future research. Journal of Ecology, 99 (3), 656, 2011.

6. BI W.X., WENG B.S., YUAN Z., YANG Y.H., XU T., YAN D.M., MA J. Evolution of Drought-Flood Abrupt Alternation and Its Impacts on Surface Water Quality from 2020 to 2050 in the Luanhe River Basin. International Journal of Environmental Research and Public Health, 16 (5), 691, 2019.

7. ZHU R., WU F.Y., ZHOU S., HU T.S., HUANG J., GAO Y. Cumulative effects of drought-flood abrupt alternation on the photosynthetic characteristics of rice. Environmental and Experimental Botany, 169, 103901, 2020.

8. WU Z.W., HE J.H., LI J.P., JIANG Z.H. The summer drought-flood coexistence in the middle and lower reaches of the Yangtze River and analysis of its air-sea 
background feathers in anomalous years. Chinese Journal of Atmospheric Sciences, 30 (4), 570, 2006.

9. FANG W., HUANG S.Z., HUANG G.H., HUANG Q., WANG H., WANG L., ZHANG Y., LI P., MA L. Copulasbased risk analysis for inter-seasonal combinations of wet and dry conditions under a changing climate. International Journal of Climatology, 39 (4), 2005, 2018.

10. HOOVER D.L., KNAPP A.K., SMITH M.D. Resistance and resilience of a grassland ecosystem to climate extremes. Ecology, 95 (9), 2646, 2014.

11. JUMP A.S., RUIZ-BENITO P., GREENWOOD S., ALLEN C.D., KITZBERGER T., FENSHAM R., MARTINEZ-VILALTA J., LLORET FRANCISCO. Structural overshoot of tree growth with climate variability and the global spectrum of drought-induced forest dieback. Global Change Biology, 23 (9), 3742, 2017.

12. BARROS C., GUEGUEN M., DOUZET R., CARBONI M., BOULANGEAT I., ZIMMERMANN N.E., MUNKEMULLER T., THUILLER W. Extreme climate events counteract the effects of climate and land-use changes in Alpine tree lines. Journal of Applied Ecology, 54 (1), 39, 2017.

13. BELLARD C., BERTELSMEIER C., LEADLEY P., THUILLER W., COURCHAMP F. Impacts of climate change on the future of biodiversity. Ecology Letters, 15, $365,2012$.

14. ZHENG C., TANG X.G., GU Q., WANG T.X., WEI J., SONG L.S., MA M.G. Climatic anomaly and its impact on vegetation phenology, carbon sequestration and wateruse efficiency at a humid temperate forest. Journal of hydrology, 565, 150, 2018.

15. LIU D.J., ESTIARTE M., OGAYA R., YANG X.H., PEÑUELAS J. Shift in community structure in an earlysuccessional Mediterranean shrubland driven by long-term experimental warming and drought and natural extreme droughts. Global Change Biology, 23 (10), 4267, 2017.

16. MIRANDA J.D., PADILLA F.M., LAZARO R., PUGNAIRE F.I. Do changes in rainfall patterns affect semiarid annual plant communities? Journal of Vegetation Science, 20 (2), 269, 2009.

17. RAKEFET S.N., TAL S., AVI P. Continuous droughts' effect on herbaceous vegetation cover and productivity in rangelands: results from close-range photography and spatial analysis. International Journal of Remote Sensing, 34 (17), 6263, 2013.

18. FAY P.A., BLAIR J.M., SMITH M.D., NIPPERT J.B., CARLISLE J.D., KNAPP A.K. Relative effects of precipitation variability and warming on tallgrass prairie ecosystem function. Biogeosciences, 8 (10), 3053, 2011.

19. MCDOWELL N.G., FISHER R.A., XU C.G., DOMEC J.C., HOLTTA T., MACKAY D.S., SPERRY J.S., BOUTZ A., DICKMAN L., GEHRES N., et al. Evaluating theories of drought-induced vegetation mortality using a multimodel-experiment framework. New Phytologist, 200 (2), 304, 2013.

20. MANOLI G., HUANG C.W., BONETTI S., DOMEC J.C., MARANI M., KATUL G. Competition for light and water in a coupled soil-plant system. Advances in Water Resources, 108, 216, 2017.

21. MANZONI S., KATUL G., PORPORATO A. A dynamical system perspective on plant hydraulic failure. Water Resources Research, 50 (6), 5170, 2014.

22. TZENG H.Y., WANG W., TSENG Y.H., CHIU C.A., KUO C.C., TSAI S.T. Tree mortality in response to typhooninduced floods and mudslides is determined by tree species, size, and position in a riparian Formosan gum forest in subtropical Taiwan. Plos One, 13 (1), e0190832, 2018.

23. FELTON A.J., PULLARO S.Z., SMITH M.D. Semiarid ecosystem sensitivity to precipitation extremes: weak evidence for vegetation constraints. Ecology, 100 (2), e02572, 2019.

24. LI W.T., DU J.K., LI S.F., ZHOU X.B., DUAN Z., LI R.J., WU S.Y., WANG S.S., LI M.H. The variation of vegetation productivity and its relationship to temperature and precipitation based on the GLASS-LAI of different African ecosystems from 1982 to 2013. International Journal of Biometeorology, 63 (7), 847, 2019.

25. HARPER C.W., BLAIR J.M., FAY P.A., KNAPP A.K., CARLISLE J.D. Increased rainfall variability and reduced rainfall amount decreases soil $\mathrm{CO}_{2}$ flux in a grassland ecosystem. Global Change Biology, 11 (2), 322, 2005.

26. ZEPPEL M.J.B., WILKS J.V., LEWIS J.D. Impacts of extreme precipitation and seasonal changes in precipitation on plants. Biogeosciences, 11 (11), 3083, 2014.

27. JIANG P., LIU H.Y., PIAO S.L., CIAIS P., WU X.C., YIN Y., WANG H. Enhanced growth after extreme wetness compensates for post-drought carbon loss in dry forests. Nature Communications, 10, 195, 2019.

28. ANDEREGG W.R.L., PLAVCOVÁ L., ANDEREGG L.D.L., HACKE U.G., BERRY J.A., FIELD C.B. Drought's legacy: multiyear hydraulic deterioration underlies widespread aspen forest die-off and portends increased future risk. Global Change Biology, 19 (4), 1188, $2013 a$.

29. OU Y., ROUSSEAU A.N., WANG L.X., YAN B.X., GUMIERE T., ZHU H. Identification of the alteration of riparian wetland on soil properties, enzyme activities and microbial communities following extreme flooding. Geoderma, 337, 825, 2019.

30. SUN G., WANG Z.Y., BARKER X.Z., ZHANG N.N., WU N., LIU L., LEI Y.B. Biotic and abiotic controls in determining exceedingly variable responses of ecosystem functions to extreme seasonal precipitation in a mesophytic alpine grassland. Agricultural and Forest Meteorology, 228, 180, 2016.

31. XU H.J., WANG X.P., ZHANG X.X. Decreased vegetation growth in response to summer drought in Central Asia from 2000 to 2012. International Journal of Applied Earth Observation and Geoinformation, 52, 390, 2016.

32. WU X.C., LIU H.Y., LI X.Y. Differentiating drought legacy effects on vegetation growth over the temperate Northern Hemisphere. Global Change Biology, 24 (1), 504, 2018.

33. LI X.Y., LI Y., CHEN A.P., GAO M.D., SLETTE I.J., PIAO S.L. The impact of the $2009 / 2010$ drought on vegetation growth and terrestrial carbon balance in Southwest China. Agricultural and Forest Meteorology, 269, 239, 2019.

34. DAVID L.H., MICHAEL C.D., JAYNE B. Pulse-drought atop press-drought: unexpected plant responses and implications for dryland ecosystems. Oecologia, 179 (4), 1211, 2015.

35. LAWSON J.R., FRYIRS K.A., LEISHMAN M.R. Hydrological conditions explain variation in wood density in riparian plants of south-eastern Australia. Journal of Ecology, 103 (4), 945, 2015.

36. MATUSICK G., RUTHROF K.X., KALA J., BROUWERS N.C., BRESHEARS D.D., HARDY GILES E.S.J. Chronic historical drought legacy exacerbates tree mortality and crown dieback during acute heatwave-compounded drought. Environmental Research Letters, 13 (9), 095002, 2018. 
37. KRAMER K., VREUGDENHIL S.J., VAN DER WERF D.C. Effects of flooding on the recruitment, damage and mortality of riparian tree species: A field and simulation study on the Rhine floodplain. Forest Ecology and Management, 255 (11), 3893, 2008.

38. HUANG K.C., YI C.X., WU D.H., ZHOU T., ZHAO X., BLANFORD W.J., WEI S.H., WU H., LING D., LI Z. Tipping point of a conifer forest ecosystem under severe drought. Environmental Research Letters, 10 (2), 024011, 2015.

39. RODRÍGUEZ A., DURÁN J., REY A., BOUDOURIS I., VALLADARES F., GALLARDO A., YUSTE J.C. Interactive effects of forest die-off and drying-rewetting cycles on $\mathrm{C}$ and $\mathrm{N}$ mineralization. Geoderma, 333, 81, 2019.

40. IBÁÑEZ B., GÓMEZ-APARICIO L., STOLL P., ÁVILA J.M., PÉREZ-RAMOS I.M., MARAÑÓN T. A neighborhood analysis of the consequences of Quercus suber decline for regeneration dynamics in Mediterranean forests. Plos One, 10 (2), e0117827, 2015.

41. YI C.X., RUSTIC G., XU X.Y., WANG J.X., DOOKIE A., WEI S.H., HENDREY G., RICCIUTO D., MEYERS T., NAGY Z., PINTER K. Climate extremes and grassland potential productivity. Environmental Research Letters, 7 (3), 035703, 2012.

42. MCDOWELL N., POCKMAN W.T., ALLEN C.D., BRESHEARS D.D., COBB N., KOLB T., PLAUT J., SPERRY J., WEST A., WILLIAMS D.G., YEPEZ E.A. Mechanisms of plant survival and mortality during drought: Why do some plants survive while others succumb to drought? New Phytologist, 178 (4), 719, 2008.

43. CHOAT B., BRODRIBB T.J., BRODERSEN C.R., DUURSMA R.A., LÓPEZ R., MEDLYN B.E. Triggers of tree mortality under drought. Nature, 558 (7711), 531, 2018.

44. LIU Y.L., PAROLARIB A.J., KUMARA M., HUANG C.W., KATUL G.G., PORPORATO A. Increasing atmospheric humidity and $\mathrm{CO} 2$ concentration alleviate forest mortality risk. Proceedings of the National Academy of Sciences of the United States of America, 114 (37), 9918, 2017.

45. KURSAR T.A., ENGELBRECHT B.M.J., BURKE A., TYREE M.T., OMARI B.E.I., GIRALDO J.P. Tolerance to low leaf water status of tropical tree seedlings is related to drought performance and distribution. Functional Ecology, 23 (1), 93, 2009.

46. URLI M., PORTÉ A.J., COCHARD H., GUENGANT Y., BURLETT R., DELZON S. Xylem embolism threshold for catastrophic hydraulic failure in angiosperm trees. Tree Physiology, 33 (7), 672, 2013.

47. PLAUT J.A., YEPEZ E.A., HILL J., PANGLE R., SPERRY J.S., POCKMAN W.T., MCDOWELL N.G. Hydraulic limits preceding mortality in a pinon-juniper woodland under experimental drought. Plant Cell and Environment, 35 (9), 1601, 2012.

48. KUKOWSKI K., SCHWINNING S., SCHWARTZ B. Hydraulic responses to extreme drought conditions in three co-dominant tree species in shallow soil over bedrock. Oecologia, 171 (4), 819, 2013.

49. RICE K.J., MATZNER S.L., BYER W., BROWN J.R. Patterns of tree dieback in Queensland, Australia: the importance of drought stress and the role of resistance to cavitation. Oecologia, 139 (2), 190, 2004.

50. ANDEREGG W.R.L., BERRY J.A., SMITH D.D., SPERRY J.S., ANDEREGG L.D.L., FIELD C.B. The roles of hydraulic and carbon stress in a widespread climate-induced forest die-off. Proceedings of the National Academy of Sciences of the United States of America, 109 (1), 233, 2012.

51. ANDEREGG L.D.L., ANDEREGG W.R.L., ABATZOGLAU J., HAUSLADEN A.M., BERRY J.A. Drought characteristics' role in widespread aspen forest mortality across Colorado, USA. Global Change Biology, 19 (5), 1526, 2013.

52. ANDEREGG W.R.L., KLEIN T., BARTLETT M., SACK L., PELLEGRINI A.F.A., CHOAT B., JANSEN S. Metaanalysis reveals that hydraulic traits explain cross-species patterns of drought-induced tree mortality across the globe. Proceedings of the National Academy of Sciences of the United States of America, 113 (18), 5024, 2016.

53. PLAUT J., WADSWORTH W.D., PANGLE R., YEPEZ E.A., MCDOWELL N.G., POCKMAN W.T. Reduced transpiration response to precipitation pulses precedes mortality in a pinon-juniper woodland subject to prolonged drought. New Phytologist, 200 (2), 375, 2013.

54. ANDEREGG W.R.L. Spatial and temporal variation in plant hydraulic traits and their relevance for climate change impacts on vegetation. New Phytologist, 205 (3), 1008, 2015.

55. WU W.H., YANG S.H., HAN Y.Z., LI Y.Z., FU Y., MAO T.L., ZHANG X.Q., ZHANG S.Q., YUAN M., ZHANG J., YE D., WANG Y., CHEN Y.F., CHEN Z.Z., REN D.T., JIANG C.F., LI J.G., ZHANG J., TANG S.J. Plant physiology, $3^{\text {rd }}$ ed.; Science Press: Beijing, China, 46, 2019 [In Chinese].

56. YANG D.W., LEI H.M., CONG Z.T. Overview of the research status in interaction between hydrological processes and vegetation in catchment. Journal of Hydraulic Engineering, 41 (10), 1142, 2010.

57. LIU J.K., ZHANG Z.M., ZHANG M.X. Impacts of forest structure on precipitation interception and runoff generation in a semiarid region in northern China. Hydrological Processes, 32 (15), 2362, 2018.

58. FATHIZADEH O., HOSSEINI S.M., ZIMMERMANN A., KEIM R.F., DARVISHI B.A. Estimating linkages between forest structural variables and rainfall interception parameters in semi-arid deciduous oak forest stands. Science of The Total Environment, 601, 1824, 2017.

59. GHIMIRE C.P., BRUIJNZEEL L.A., LUBCZYNSKI M.W., RAVELONA M., ZWARTENDIJK B.W., VAN MEERVELD H.J.I. Measurement and modelling of rainfall interception by two differently aged secondary forests in upland Eastern Madagascar. Journal of Hydrology, 545, 212, 2017.

60. YU X.N., HUANG Y.M., LI E.G., LI X.Y., GUO W.H. Effects of rainfall and vegetation to soil water input and output processes in the Mu Us Sandy Land, northwest China. Catena, 161, 96, 2018.

61. WU G.L., LIU Y., YANG Z., CUI Z., DENG L., CHANG X.F., SHI Z.H. Root channels to indicate the increase in soil matrix water infiltration capacity of arid reclaimed mine soils. Journal of Hydrology, 546, 133, 2017.

62. HUANG Z., TIAN F.P., WU G.L., LIU Y., DANG Z.Q. Legume grasslands promote precipitation infiltration better than gramineous grasslands in arid regions. Land Degradation and Development, 28 (1), 309, 2017.

63. AMENU G.G., KUMAR P. A model for hydraulic redistribution incorporating coupled soil-root moisture transport. Hydrology and Earth System Science, 12 (1), 55, 2008. 
64. WANG H.L., TETZLAFF D., SOULSBY C. Modelling the effects of land cover and climate change on soil water partitioning in a boreal headwater catchment. Journal of Hydrology, 558, 520, 2018.

65. LI S., LIANG W., FU B.J., LU Y.H., FU S.Y., WANG S., SU H.M. Vegetation changes in recent large-scale ecological restoration projects and subsequent impact on water resources in China's Loess Plateau. Science of the Total Environment, 569, 1032, 2016.

66. KOTHYARI B.P., VERMA P.K., JOSHI B.K., KOTHYARI U.C. Rainfall-runoff-soil and nutrient loss relationships for plot size areas of Bhetagad watershed in Central Himalaya, India. Journal of hydrology, 293, 137, 2004.

67. WANG S.P., ZHANG Z.Q., MCVICAR T.R., ZHANG J.J., ZHU J.Z., GUO J.T. An event-based approach to understanding the hydrological impacts of different land uses in semi-arid catchments. Journal of hydrology, 416, 50, 2012.

68. MATYAS C., SUN G. Forests in a water limited world under climate change. Environmental Research Letters, 9 (8), 085001, 2014.

69. ANDEREGG W.R.L., KANE J.M., ANDEREGG L.D.L. Consequences of widespread tree Mortality triggered by drought and temperature stress. Nature Climate Change, 1 (3), 30, 2013b.

70. HATA K., KAWAKAMI K., KACHI N. Increases in soil water content after the mortality of non-native trees in oceanic island forest ecosystems are due to reduced water loss during dry periods. Science of the Total Environment, 545, 372, 2016.

71. BIEDERMAN J.A., SOMOR A.J., HARPOLD A.A., GUTMANN E.D., BRESHEARS D.D., TROCH P.A., GOCHIS D.J., SCOTT R.L., MEDDENS A.J.H., BROOKS P.D. Recent tree die-off has little effect on streamflow in contrast to expected increases from historical studies. Water Resources Research, 51 (12), 9775, 2015.

72. ZIMMERMANN B., ZIMMERMANN A., SCHECKENBACH H.L., SCHMID T., HALL J.S., VAN BREUGEL M. Changes in rainfall interception along a secondary forest succession gradient in lowland Panama. Hydrology and Earth System Sciences, 17 (11), 4659, 2013.
73. BATHURST J.C., IROUMÉ A., CISNEROS F., FALLAS J., ITURRASPE R., NOVILLO M.G., URCIUOLO A., DE BIÈVRE B.; BORGES V.G., COELLO C., ET AL. Forest impact on floods due to extreme rainfall and snowmelt in four Latin American environments 1: Field data analysis. Journal of Hydrology, 400 (3-4), 281, 2011.

74. ZHANG Y.W., SHANGGUAN Z.P. The change of soil water storage in three land use types after 10 years on the Loess Plateau. Catena, 147, 87, 2016.

75. BOSCH J.M., HEWLETT J.D. A review of catchment experiments to determine the effect of vegetation changes on water yield and evapotranspiration. Journal of Hydrology, 55, 3, 1982.

76. STEDNICK J.D. Monitoring the effects of timber harvest on annual water yield. Journal of Hydrology, 176, 79, 1996.

77. LI X.R., ZHANG Z.S., HUANG L., WANG X.P. Review of the ecohydrological processes and feedback mechanisms controlling sand-binding vegetation systems in sandy desert regions of China. Chinese Science Bulletin, 58 (13), 1483, 2013.

78. YU Z.B., LUE H.S., ZHU Y.H., DRAKE S., LIANG C. Long-term effects of revegetation on soil hydrological processes in vegetation-stabilized desert ecosystems. Hydrological Processes, 24 (1), 87, 2010.

79. LI B., GAO J.R., WANG X.R., MA L., CUI Q., VEST M. Effects of biological soil crusts on water infiltration and evaporation Yanchi Ningxia, Maowusu Desert, China. International Journal of Sediment Research, 31 (4), 311, 2016.

80. Measuring ecosystem capacity to provide regulating services: forest removal and recovery at Hubbard Brook (USA). Ecological Applications, 25 (7), 2011, 2015.

81. FORD C.R., LASETER S.H., SWANK W.T., VOSE J.M. Can forest management be used to sustain waterbased ecosystem services in the face of climate change? Ecological Applications, 21 (6), 2049, 2011.

82. FARLEY K., JOBBAGY E., JACKSON R.B. Effects of afforestation on water yield: a global synthesis with implications for policy. Global Change Biology, 11 (10), 1565,2005 